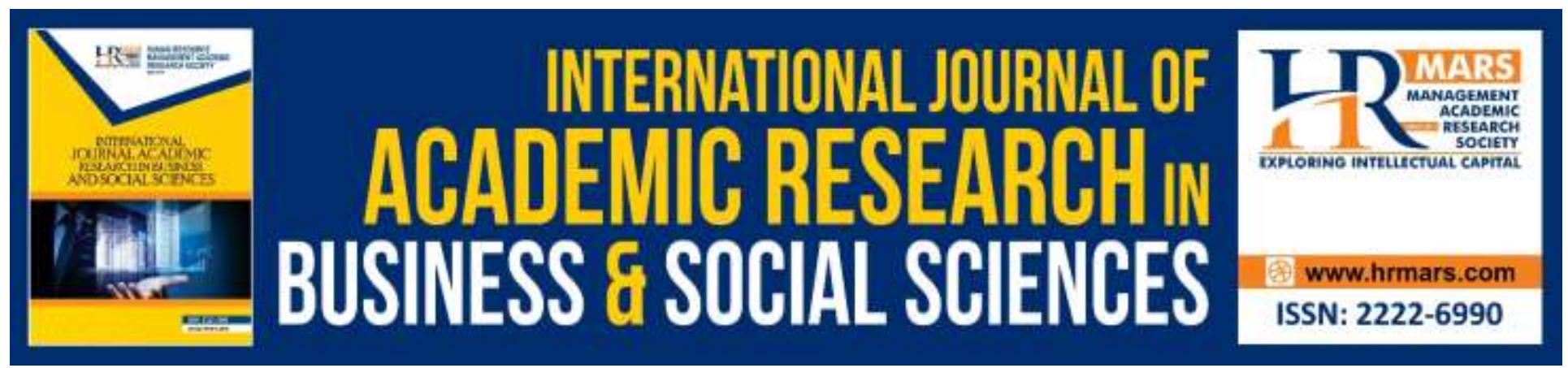

\title{
The Impact of Age, Gender, Culture and Language toward the Use of ICT for Teaching and Learning by Lecturers in University of Tripoli, Libya
}

Abdul Ghafar Mansor M. M. Mohamad, Syed Zulkarnain Syed Idrus, Amani Ali Elmetwely Ali Ibrahim

To Link this Article: http://dx.doi.org/10.6007/IJARBSS/v9-i14/6506

DOI:10.6007/IJARBSS/v9-i14/6506

Received: 22 August 2019, Revised: 17 September 2019, Accepted: 02 September 2019

Published Online: 23 October 2019

In-Text Citation: (Mohamad, Idrus, \& Ibrahim, 2019)

To Cite this Article: Mohamad, A. G. M. M. M., Idrus, S. Z. S., \& Ibrahim, A. A. E. A. (2019). The Impact of Age, Gender, Culture and Language toward the Use of ICT for Teaching and Learning by Lecturers in University of Tripoli, Libya. International Journal of Academic Research in Business and Social Sciences, 9(14), 71-82.

Copyright: (c) 2019 The Author(s)

Published by Human Resource Management Academic Research Society (www.hrmars.com)

This article is published under the Creative Commons Attribution (CC BY 4.0) license. Anyone may reproduce, distribute, translate and create derivative works of this article (for both commercial and non-commercial purposes), subject to full attribution to the original publication and authors. The full terms of this license may be seen

at: http://creativecommons.org/licences/by/4.0/legalcode

Vol. 9, No. 14, Special Issue: Education 4.0: Future Learning, Pg. 71 - 82

Full Terms \& Conditions of access and use can be found at http://hrmars.com/index.php/pages/detail/publication-ethics 


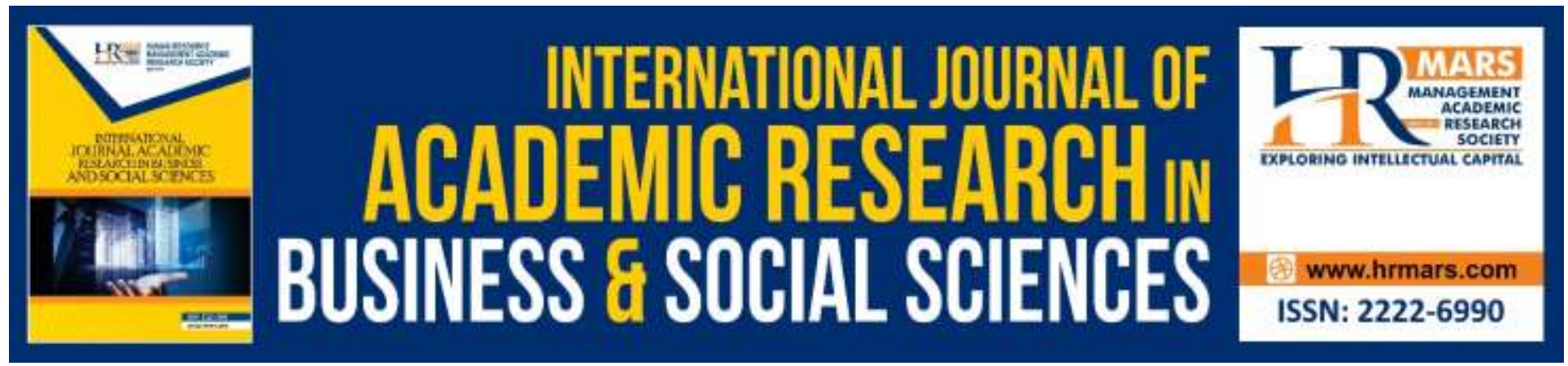

\title{
The Impact of Age, Gender, Culture and Language toward the Use of ICT for Teaching and Learning by Lecturers in University of Tripoli, Libya
}

\author{
Abdul Ghafar Mansor M. M. Mohamad, Dr. Syed Zulkarnain Syed \\ Idrus, Dr Amani Ali Elmetwely Ali Ibrahim \\ Human Development and Technocommunication (IKOM), Universiti Malaysia Perlis \\ (UniMAP), Jalankanar- Arau, 02600 Jejawi, Arau, Perlis \\ Email: abdulghafarmmm@gmail.com
}

\begin{abstract}
The educational system plays a crucial role in the development of nations, and the impact of using ICT by a lecture to deliver lecture to the student in University of Tripoli. However, this study aims to explore the impact of age, gender, culture and language toward the use of ICT by lecturer in Libya University. Moreover, previous studies highlighted that age, gender, culture, and language affect lecturers due to different countries that they went to study and the technology age affect use ICT for teaching and learning in University of Tripoli. Furthermore, the sample size of 150 lecturers participates in this study with the use of Statistical Package for the Social Sciences (SPSS) to analyze data. The finding shows that there is a significant difference between age, gender, culture, and language towards the use of ICT by lecturers in the University of Tripoli, Libya.

Keywords: Age, Gender, Culture, Language, Gamification, Technology in Education, and Information and Communication Technologies (ICT)

\section{Introduction}

Information and communication technology (ICT)has been contributed to the development of teaching and learning in education, which ICT has benefited and provides good quality to education system (Ibrahim \& Shahzad, 2015; Abukhattala, 2016). However, the Traditional method of teaching has become ineffective and boring to lecturers and student, although lecturers continuously seek novel instructional approaches, it is largely agreed that today's lecturer faced major problems in term of motivation and engagement to use ICT for teaching and learning (Dicheva, Dichev, Agre \& Angelova, 2015). Moreover, education gaming method of teaching and learning tools is to engage the lecturer to utilize a different kind of ICT tools and to increase their ability to lecture student by reducing the time of the prepared lecture, stress, and
\end{abstract}


INTERNATIONAL JOURNAL OF ACADEMIC RESEARCH IN BUSINESS AND SOCIAL SCIENCES

Vol. 9, No. 14, Special Issue: Education 4.0: Future Learning. 2019, E-ISSN: 2222-6990 @ 2019 HRMARS

cost (Alsulami, 2016). Additionally, to implement the use of educational gaming is difficult for the lecturer that has no idea or experience with the use of ICT for teaching and learning.

Moreover, ICT has been currently integrated into teaching and research work due to its usefulness (Abodher, 2014). Over the years, ICT tools have been introduced into the educational system in Libya (Abukhattala, 2016). However, the adoption of ICT for learning in Libya is Similar to other developed and developing countries such as United State, United Kingdom, Malaysia Saudi Arabia, Jordan and other countries. Therefore, the implementation of ICT in education is still in the early stage in Libya (Almansuri \& Elmansuri, 2015). While some Libyan educational sectors, especially the universities have some basic ICT tools to enhance learning in education is still in deliberation stage of adoption of ICT into their curriculum.

Furthermore, previous studies have been highlighted issues that affect the use of ICT by lecturer such as a study by Yuen (2013) highlighted that previous study neglect to investigate the cultural difference to accept the technology with the perspective of gender and age differences. However, Altun (2015) revealed that most of the lecturers in Arab countries lacked to learning the foreign language in order to help them to use ICT for teaching and learning in the classroom. similarly, very little attention on gender, age, culture and language towards the use of ICT by the lecturer (Abukhattala, 2016; Almansuri \& Elmansuri, 2015; Yuen, 2013). Additionally, Dicheva, et al., (2015) highlighted that most of the previous studies on gamification in education were conceptual research and there is a need for empirical study. In addition, a study by Grund (2015) found that there is unclear of lack of understanding regarding the effect of gamification to the education. Therefore, the previous study has been highlighted issues and problem in faced in an educational system, which limited study investigate and explore the differences and well as impact lecturer to use ICT for teaching and learning as this study intend to fill the gap.

Additionally, despite what has been mentioned from the previous discussion on issue and problem affect the use of ICT by lecturers in the University of Tripoli, Libya. Consequence, this shows that there is a need for more study and gap to fill on use ICT by the lecturer in the university. Therefore, the objective of this study is to investigate the differences between lecturer age and gender and language towards the use of ICT for teaching and learning. Similarly, this study intends to explore the impact of culture, language and gamification with the use of ICT by lecturers in the University of Tripoli, Libya. Hence, Hofstede cultural model and Unified Theory of Acceptance and Use of Technology (UTAUT), model employed to support this study.

\section{Literature Review}

Libya is an Arab country, which is located in Africa and the population of $6,408,260$. However, the official language of Libya is the Arabic language, which more than $95 \%$ of Libya can speak and write Arabic language (World Bank, 2015). Moreover, the educational system of Libya is divided into four stages, primary, secondary, college, and university. The government provides free education to all Libya citizen and the government compulsory primary and secondary school for all citizen to attend while other is not compulsory (Othman, Pislaru, Kenan \& Impes, 2013). In addition, Government provides the opportunity for all citizen to study outside the Libya with the monthly allowance, free tuition fees and free travel ticket and others, these benefits are given

room for Libyan to study in the different language as well as having different cultural experience 
INTERNATIONAL JOURNAL OF ACADEMIC RESEARCH IN BUSINESS AND SOCIAL SCIENCES

Vol. 9, No. 14, Special Issue: Education 4.0: Future Learning. 2019, E-ISSN: 2222-6990 @ 2019 HRMARS

from study abroad. Therefore, some of the lecturer in the university in Libya studies their undergraduate in Libya and some go abroad to for complete their postgraduate degree. Hence, few of them study undergraduate and post graduate outside Libya (Abukhattala, 2016; Almansuri \& Elmansuri, 2015).

\section{USE of ICT}

The role of ICT in Libya University is to improve the learning skill as a new method for delivering teaching to the student in the classroom. According to Drigas and Charami (2014), teaching itself is an art, which is constantly changing depending on the era we live and teach in. However, the improvement of technology for teaching and learning has been found that using technology can benefit to enhance teaching by transforming the process of delivering lecture to the student through the use of technology (Othman, Pislaru \& Impes 2014). Another study highlighted that implementation of ICT in the lecture room will change the attitude of the lecturer, which the changes can play important role in integration of ICT will bring a positive influence to the lecturer (Abukhattala, 2016; Alsulami, 2016). Almansuri \& Elmansuri (2015) stated that using the ICT for teaching and learning is considered as an easy way to deliver the lecture to the student. Klella (2016) argued that ICT inside the class room is helpful and useful to the lecturer to achieve better teaching and learning. Elzawi (2015) found that the use of ICT can improve the teaching and learn in Libya University through the implementation of ICT in the lecture room in order to provide ease of delivering the lecture to the student. Therefore, ICT can change and enhance lecturer to use ICT when they perceive it usefulness, experience, and contribution to their performance in the time of time-saving, stress reduction and easiness of use ICT in Libya University.

\section{Gamification}

Gamification has become a interest topic in the field of research and gaining interest to searchers and scholars in different context of study such as business, marketing, corporate management and others (Grund, 2015; Dicheva, et. at., 2015). However, Gamification, characterized by Deterding et al. (2011) as the utilization of design game elements of non-game field that is easy to understand, which is perceived as new and quickly developing field. Meanwhile, the idea of gamification is unique in relation to that of an educational game, depicts the outline of undeniable amusements games for non-entertainment purposes, "gamified" applications only utilize components of games. The expression of gamification is quite recent according to Dicheva, et. at., (2015) stated that use of gamification was firstly used in 2008 yet it did not see across the board appropriation before the middle of 2010. However, the use of gamification in education has been highlighted as method of motivation and fundamental to teaching and learning.

Moreover, previous studies have been investigation of gamification in education such as Dicheva, Dichev, Agre and Angelova (2015) highlighted that most of universities are facing several problem regarding teaching student in the lecture room, which lecturer did not have any motivation and enjoyment to teach with traditional method of teaching. The authors revealed that gamification can provide more opportunity to lecturer and benefited the student when there is non-gaming teaching method such as computer, projector, online assignment and examination will enhance lecturer and make teaching easy for them. Similarly, Challco1, et al (2016) explored the effects of using game elements in specific educational contexts and found that 
gamification can innovate teaching and learning through the use of technology. Another study by Grund (2015) studied the use of games and game elements beyond entertainment and outlines their theoretical foundations and the result revealed that gamification has a facility to motivation teaching and learning. Additionally, Jackson (2016) investigated the integration of gamification into the education curriculum and founds that gamification can be integrated effectively into education to motivate students and enhance learning. Therefore, base on previous studies has highlighted and mentioned that gamification has a relation with the use of ICT for teaching and learning, which it may enhance Libyan university lecturer to use ICT for teaching and learning.

\section{Age}

The UTAUT model highlighted that age is an essential demographic that has a significance differences towards the acceptance of technology (Venkatesh, Thong \& Xu, 2012). (UTAUT) was developed by Venkatesh, Morris, Davis et al (2003) with the aim of exploring the intention and the actual usage of a user to utilize a certain technology and the factors affect their intention to use. Four constructs were developed from eight theories to become UTAUT model. Furthermore, among of the constructs use are gender and age which is adapt to this study

However, Age is among of factor considered affecting the acceptance of technology either in information technology or information system believes that age has the impact to accept the use of technology (Tarhini, Hone \& Liu (2014). A study by Yuen (2013) highlighted that age plays an important role towards the acceptance of technology and has a significant difference between user ages. Moreover, Tarhini, Hone and Liu (2014) stated that age is the extent of showing the intent or willingness to accept the use of technology for education purpose and found that there is differences in aging of the user to accept the use of technology. Furthermore, Kipturgo, Kivuti-Bitok, Karani, and Muiva (2014) revealed that age is the major contributor to the acceptance of the technology. Similally, Ifinedo (2015) found that age of ICT users is the matter on how to operate technology and reveals that age has a significance differences to utilize ICT. Therefore, a study by Burnett (2016) highlighted that age of lecturer will determine the acceptance and the use of technology for teaching and learning. Thus is similar to the study by measuring the different between the lecturer age in Libya university toward the use of ICT.

\section{Gender}

The previous study has been used the gender as moderator to measure the effect of gender towards the acceptance of technology (Venkatesh et al., 2012). However, Gender differences have been studied in a diverse range of disciplines such gender differences (Goswami \& Dutta, 2015). Moreover, gender has been considered to modeling user acceptance or use of ICT, which is originated from gender schema theory (Bem, 1981) and other technology acceptance models. Previous literature has shown that men and woman are different in their decision-making processes, and they usually use different socially constructed cognitive structures (Venkatesh \& Morris, 2000). Furthermore, Goswami and Dutta (2015) studied gender differences in acceptance of technology and the finding shows that male has a significant difference to accept the use of technology than female. Therefore, this study intends to investigate the gender differences between the male and female lecturer in the university in Libya. 


\section{Culture}

Hofstede cultural theory originated in 1965 by Geert Hofstede to describe the effect of culture in society and the influence on communication in order to relate it with behavior. However, the model has been used in a different context of study such as marketing, management, account, technology, education, and others to study the different culture. Additionally, Hofstede (1984) defines culture as "the collective programming of the mind which distinguishes the members of one human group from another. However, Trompenaars and Hampden-Turner (1998) described culture As a member of a particularistic culture, which emphasizes more on friendships and close relationships. Furthermore, some study has been investigated the Hofstede theory with the acceptance of technology (Carey \& Kacmar, 2010). Information security culture (Dollah \& ALI, 2012). Effect of culture on teaching and learning (Adeoye, 2014). Therefore, previous study has found that culture has effect and influence toward the use of technology in education.

A study by Kacmar (2010) studied the impact of culture towards the technology acceptance and the result shows that culture has a relationship with the use of technology similarly, Yuen (2013) found that culture has no differences regarding acceptance of the technology. Similarly, past studies have been found that culture has a relationship with the use of ICT for teaching and learning (Kenan, Pislaru \& Elzawi, 2014; Rhema \& Miliszewska, 2014). Therefore, culture can influence lecturers towards the use of ICT for teaching and learning in Libya University.

\section{Language}

In modern technology, it is important for lecturers to learn foreign language in order to integrate the use of ICT as a new method of teaching in the lecture room (Pun, 2014). However, Using ICT for teaching and learning is useful for the lecturer to provide quality of teaching and learning with less stress to lecture student. Additionally, ICT is the powerful tool to motivate lecturer and make teaching and learning more interest and easy for the student (Rhema \& Miliszewska, 2014). Moreover, using ICT gaming in a proper way will increase the interest foreign language for teaching and learning with the use of computer game and internet will has a positive impact to the lecturer when they use it correctly (Ilter, 2015). A study by Ishihara and Cohen (2014) argued that learning the English language is not an easy task. Therefore, teaching methods for the language have also undergone a myriad of changes, and each one has been geared toward facilitating student (Alsulami, 2016).

According to Pun (2014) investigated that using a foreign language for teaching in nonEnglish speaking countries will face the different problem without the use of technology to motivate the lecturer and also to improve their learning skill. Another, Altun, (2015) studied the technology based foreign language for teaching and learning and the finding shows that effect towards the use ICT for teaching and learning. Undoubtedly, utilizing foreign language has a positive effect to the lecturer for teaching and learning through the use of ICT. Similarly, ilter (2015) investigated how ICT affects the language learning process at an early age and the author found that foreign language has a difference to the use of ICT for teaching and learning. Therefore, language can influence lecturer towards the use of technology in Libya University. 
INTERNATIONAL JOURNAL OF ACADEMIC RESEARCH IN BUSINESS AND SOCIAL SCIENCES

Vol. 9, No. 14, Special Issue: Education 4.0: Future Learning. 2019, E-ISSN: 2222-6990 @ 2019 HRMARS

\section{Methodology}

This study employed the quantitative method of research to investigate the impact of age, gender, culture, and language toward the use of ICT (zikmund (2005), and the sample of the study is lecturers from the university of Tripoli, Libya. However, non-probability sample was used by adapt convenience sampling to select 150 respondents that will participate in this study (saunders \& lewis, 2012). Furthermore, the instrument of this study is adapted questionnaire from previous studies (Cózar-Gutiérrez \& Sáez-López, 2016; Tri \& Nguyen, 2014; Ghavifekr \& Rosdy, 2015). and five points Likert scale was used to measure entire items "Strongly Disagree (1)" and "Strongly Agree (5)". Hence, the data collection was done by provide the questionnaire to the lecturers during the office hour and the return took some weeks before getting the questionnaire back from the respondents. Therefore, the use of Statistical Package for the Social Sciences (SPSS) was used to analyze the data.

\section{Findings}

The respondent of this study are male and female lecturers in university of Tripoli, Libya. However, the sample of 150 (100\%) lecturers participated in this study, 102(68\%) are male respondents while female are 48(32\%). Age of respondents between 25 is $22(14.7 \%)$ respondents, 26 to 35 is $35(23.3 \%)$ respondents, 36 to 45 is $46(30.7 \%), 46$ to 55 is $36(24 \%), 55$ and above $11(7.3 \%)$ respondents. Similarly, language of respondent study such as Arabic 32(21.3\%), French 23(15.3\%), English 54(36\%), German 29(19.3) Spanish 12(8\% and the tatal were $150(100 \%)$ respondents predicated in this study.

Reliability refers to the degree to which a scale produces reliable outcomes if the estimations are repeated various circumstances. Moreover, Tavakol and Dennick, (2011) highlighted that coefficient scores between 0.5 to 0.6 is consider as poor, between 0.6 to 0.7 is consider as moderate, scale between 0.7 and 0.8 consider as highly good between 0.8 and 0.9 scale is excellent and Alpha coefficient range is equal to or more than 0.9. Therefore the below table show the reliability test of 0.807 for 20 items of four variables of culture, language, gamification and use of ICT.

Table 1: Reliability

\begin{tabular}{cc}
\hline $\begin{array}{c}\text { Cronbach's } \\
\text { Alpha }\end{array}$ & $\begin{array}{c}\text { N of } \\
\text { Items }\end{array}$ \\
\hline .807 & 20 \\
\hline
\end{tabular}

\section{Regression Analysis}

Regress analysis was use to determine and predict the dependent variable, which is use of ICT and independent variable are Age, Gender, Culture, Language And Gamification as well as relative contribution of each of the predictors to the total variance explained (Field, 2009). 
INTERNATIONAL JOURNAL OF ACADEMIC RESEARCH IN BUSINESS AND SOCIAL SCIENCES

Vol. 9, No. 14, Special Issue: Education 4.0: Future Learning. 2019, E-ISSN: 2222-6990 @ 2019 HRMARS

Table 2: Regression Result

\begin{tabular}{lcccc}
\hline Variables & $\begin{array}{c}\text { Std. } \\
\text { Error }\end{array}$ & Beta & t-value & $\begin{array}{c}\text { p- } \\
\text { value. }\end{array}$ \\
\hline Gamification & .102 & .321 & 3.970 & .000 \\
Language & .068 & -.030 & -.368 & .714 \\
Culture & .064 & .176 & 2.225 & .028 \\
\hline
\end{tabular}

As shown in Table 2 shows the result from the regression analysis test, which reveals that there is two positive and one negative result from this study. However, gamification is significant to explain this study with $(\beta=-0.321, t=3.970, p<0.01)$ and there is positive relationship between gamification and the use of ICT which is in line with previous studies (Grund, 2015; Dicheva, et al., 2015; Jackson,2016). Furthermore, language has a negative significance $(\beta=-0.030, t=-$ $0.368 p<0.714$ ) and there is no relationship between language and the use of ICT, this is baseline with past studies (ilter, 2015; Ishihara \& Cohen 2014). Additionally, culture is supported with the level of $(\beta=0.064, t=2.225, p>0.05)$ and there is positive relationship between the culture and the use of ICT, hence previous studies revealed positive result with the use of ICT (Yuen, 2013; Adeoye, 2014). Therefore, in line with the objective of this study to test if there is any differences between male and female lecturer towards the use of ICT for teaching and learning student in the classroom. Therefore, this study use t-test to check if there is different between gender (Male or Female) and the use of ICT for teaching and learning by lecturer.

Table 3: Independent t-test

\begin{tabular}{llccccc}
\hline Construct & Items & $\mathrm{F}$ & Sig. & $\mathrm{t}$ & $\mathrm{df}$ & $\begin{array}{c}\text { Sig. (2- } \\
\text { tailed) }\end{array}$ \\
\hline Use of ICT & Male & 24.39 & .00 & - & 148 & .233 \\
& & 5 & 0 & 1.197 & & .124 \\
& Female & & - & 1.547 & 2 & \\
\hline
\end{tabular}

The Table 3 shows that there is difference between male and female lecturer towards the use of ICT for teaching and learning at the significance level of $p<0.01$. Additionally, in order to test the difference of lecturer age and language towards the use of ICT for teaching and learning. Hence the below Table 4 show that there is significance differences at the level of (t-value4,145 $=7.393, p<0.01$ ), highlight the differences between the language (Arabic, English, French, Spanish and German) towards the use of ICT to teach and learning the student in the classroom. Similarly, age (between 25 to 55 with 10 intervals) with the use of ICT. THUS, the result reveal that there is significance at the level of ( $t$-value4,145 $=4.111, p<0.01$ ), shows difference between the age of lecturer and use of ICT. Therefore, this study highlighted that there is differences between age of lecturer and language they used during their study towards the use of ICT in order to teaching student in university of Tripoli, Libya. 
INTERNATIONAL JOURNAL OF ACADEMIC RESEARCH IN BUSINESS AND SOCIAL SCIENCES

Vol. 9, No. 14, Special Issue: Education 4.0: Future Learning. 2019, E-ISSN: 2222-6990 @ 2019 HRMARS

Table 4: One way Anova

\begin{tabular}{|c|c|c|c|c|c|c|}
\hline use of ICT & & $\begin{array}{l}\text { Sum of } \\
\text { Squares }\end{array}$ & $\mathrm{df}$ & Mean Square & $\mathrm{F}$ & Sig. \\
\hline \multirow{2}{*}{$\begin{array}{l}\text { Langu } \\
\text { age }\end{array}$} & $\begin{array}{l}\text { Between } \\
\text { Groups }\end{array}$ & 6.432 & 4 & 1.608 & 7.393 & .000 \\
\hline & Within Groups & 31.535 & 145 & .217 & & \\
\hline \multirow{4}{*}{ Age } & $\begin{array}{l}\text { Total } \\
\text { Between }\end{array}$ & 37.967 & 149 & & & \\
\hline & $\begin{array}{l}\text { Groups } \\
\text { Within Groups }\end{array}$ & 3.867 & 4 & 0.967 & 4.111 & 0.003 \\
\hline & \multirow[b]{2}{*}{ Total } & 34.1 & 145 & 0.235 & & \\
\hline & & 37.967 & 149 & & & \\
\hline
\end{tabular}


INTERNATIONAL JOURNAL OF ACADEMIC RESEARCH IN BUSINESS AND SOCIAL SCIENCES

Vol. 9, No. 14, Special Issue: Education 4.0: Future Learning. 2019, E-ISSN: 2222-6990 @ 2019 HRMARS

\section{Conclusion}

This study is in line with the previous study with the use of ICT and technology for teaching and learning student in the lecture room. However, this study has be proved that there is different between the age and languages of lecturer in university of Tripoli, Libya toward the use of ICT for teaching and learning student in the lecturer room. Similarly, gamification and culture have positive to this study while language is negative to this study. Therefore, the language still affects lecturer to use ICT in the lecturer room and this study is recommended to must of university lecturer in Libya to look forward to the language of ICT and technology installed to the lecturer room in order for them to use. And future research can carry out a study to the language of instruction of the lecturers during their time of study and how its affect the use of ICT in the lecturer room.

\section{References}

Abodher, S. M. (2014). The Extent of Information Communication Technology Use in the University of Tripoli, Libya. British Journal of Education, Society \& Behavioural Science $4(11)$.

Abukhattala, I. (2016). The use of technology in language classrooms in Libya. International Journal of Social Science and Humanity, 6(4), 262.

Adeoye, B. F. (2014). Effects of Information Capitalism and Globalization on Teaching and Learning. IGI Global.

Almansuri, A. A., \& Elmansuri, R. A. (2015). Utilizing E-Learning Systems in the Libyan Universities: Case Study; Tripoli University, Faculty of Engineering. International Association for Development of the Information Society.

Alsulami, S. (2016). The effects of technology on learning English as a foreign language among female EFL students at Effatt college: An exploratory study. Studies in Literature and Language, 12(4), 1-16.

Altun, M. (2015). The integration of technology into foreign language teaching. International Journal on New Trends in Education and Their Implications, 6(1), 22-27.

Burnett, C. (2016). The Digital Age And Its Implications For Learning And Teaching In The Primary School. Cambridge Primary Review Trust

Carey, J. M., \& Kacmar, C. J. (2010). Cultural and Language Affects on Technology Acceptance and Attitude: Chinese Perspectives. International Journal of Information Technology, 16(1), 119.

Challco, G. C., Mizoguchi, R., Bittencourt, I. I., \& Isotani, S. (2015, August). Gamification of Collaborative Learning Scenarios: Structuring Persuasive Strategies Using Game Elements and Ontologies. In International Workshop on Social Computing in Digital Education (pp. 12-28). Springer International Publishing.

Cózar-Gutiérrez, R., \& Sáez-López, J. M. (2016). Game-based learning and gamification in initial teacher training in the social sciences: an experiment with MinecraftEdu. International Journal of Educational Technology in Higher Education, 13(1), 2.

Dicheva, D., Dichev, C., Agre, G., \& Angelova, G. (2015). Gamification in education: a systematic mapping study. Journal of Educational Technology \& Society, 18(3), 75. 
INTERNATIONAL JOURNAL OF ACADEMIC RESEARCH IN BUSINESS AND SOCIAL SCIENCES

Vol. 9, No. 14, Special Issue: Education 4.0: Future Learning. 2019, E-ISSN: 2222-6990 @ 2019 HRMARS

Dollah, W., \& Ali, J. (2012). Determining factors influencing information security culture among ICT librarians. Journal of Theoretical and Applied Information Technology, 37(1).

Drigas, A., \& Charami, F. (2014). ICTs in English Learning and Teaching. IJES, 4, 5.

Elzawi, A. E. (2015). A Study on the Impact of ICT on Collaborative Learning Processes in Libyan Higher Education. International Journal of Learning, Teaching and Educational Research, 10(1).

Ghavifekr, S., \& Rosdy, W. A. W. (2015). Teaching and learning with technology: Effectiveness of ICT integration in schools. International Journal of Research in Education and Science, $1(2), 175-191$.

Goswami, A., \& Dutta, S. (2015). Gender Differences in Technology Usage-A Literature Review. Open Journal of Business and Management, 4(01), 51.

Grund, C. K. (2015). How Games and Game Elements Facilitate Learning and Motivation: A Literature Review. In Gl-Jahrestagung (pp. 1279-1293).

Hofstede, G. (1984) Cultural Consequences: International Differences In Work

Ibrahim, J. S., \& Shahzad, A., (2015). The Adoption of Blended Learning in Higher Education Institution in Nigeria. International Journal of Management and Social Sciences Research (IJMSSR) 4(10) 64-70

Ifinedo, P. (2015). The Moderating Effects of Age and Computer Knowledge on Nurses' Acceptance of Information Systems: A Canadian Study. In CONF-IRM (p. 29).

Iilter, B. G. (2015). How does technology affect language learning process at an early age?. Procedia- Social and Behavioral Sciences, 199, 311-316.

Jackson, M. (2016). Gamification in Education: A Literature Review. Nucleic acids research, 44(W1), W3-W10.

Kenan, T., Pislaru, C., \& Elzawi, A. (2014). Trends and policy issues for the e-learning implementation in Libyan universities. International Journal of Trade, Economics and Finance, 5(1), 105.

Kipturgo, M. K., Kivuti-Bitok, L. W., Karani, A. K., \& Muiva, M. M. (2014). Attitudes of nursing staff towards computerisation: a case of two hospitals in Nairobi, Kenya. BMC medical informatics and decision making, 14(1), 35.

Klella, A. S., (2016). Integrating ICT with English Teaching: Challenges and Barriers.ELT Vibes: International E-Journal For Research in ELT. 2(1).72-84

Lee, J. J., \& Hammer, J. (2011). Gamification in education: What, how, why bother. Academic exchange quarterly, 15(2), 146.

Othman, A. A., Pislaru, C., \& Impes, A. M. (2014). Improving the quality of technology-enhanced learning for computer programming courses. International Journal of Information and Education Technology, 4(1), 83.

Othman, A., Pislaru, C., Kenan, T., \&Impes, A. (2013).Analysing the effectiveness of IT strategy in Libyan higher education institutes.International Journal of Digital Information and Wireless Communications (IJDIWC), 3(3), 114-129.

Pun, M. (2014). The use of multimedia technology in English language teaching: A global perspective. Crossing the Border: International Journal of Interdisciplinary Studies, 1(1), 29-38. 
Rhema, A., \& Miliszewska, I. (2014). Analysis of student attitudes towards e-learning: The case of engineering students in Libya. Issues in Informing Science and Information Technology, 11, 169- 190.

Tarhini, A., Hone, K., \& Liu, X. (2014). Measuring the moderating effect of gender and age on elearning acceptance in England: A structural equation modeling approach for an extended technology acceptance model. Journal of Educational Computing Research, 51(2), 163184.

Tri, D. H., \& Nguyen, N. H. T. (2014). An exploratory study of ICT use in English language learning among EFL university students. Teaching English with Technology, 14(4), 32-46.

Venkatesh, V., Thong, J. Y., \& Xu, X. (2012). Consumer acceptance and use of information technology: extending the unified theory of acceptance and use of technology. MIS Quarterly, 36(1), 157-178.

Yuen, Y. Y. (2013). Gender and age effect on acceptance of internet banking: cultural comparison between United States and Malaysia. International Journal of Business and Management, $8(18), 1$. 